\title{
Positioning management accounting on the intellectual capital agenda
}

\section{Peter Cleary}

Department of Accounting, Finance and Information Systems, O’Rahilly Building, University College Cork, Cork, Ireland

E-mail: p.cleary@ucc.ie

\section{Tom Kennedy}

Department of Accounting and Finance, Kemmy Business School, University of Limerick, Ireland

E-mail: tom.kennedy@ul.ie

\section{David O'Donnell}

Intellectual Capital Research Institute of Ireland, Ballyagran,

Limerick County, Ireland

E-mail: david.odonnell@ireland.com

\section{Philip O’Regan}

Department of Accounting and Finance, Kemmy Business School, University of Limerick, Ireland

E-mail: philip.oregan@ul.ie

\section{Nick Bontis*}

DeGroote School of Business, McMaster University, Hamilton, Canada

E-mail: nbontis@mcmaster.ca

*Corresponding author

\begin{abstract}
This paper presents a conceptual framework that situates, integrates and tests, using a structural equation model, the possible contribution of management accounting systems to the management of intellectual capital (IC). Drawing on perceptual data from Chief Financial Officers (CFOs) in an ICT sector the findings are mixed. They show positive path coefficients between management accounting systems, structural capital and business performance, as proposed by the model - but none are statistically significant. Other relationships found, however, strongly support earlier work in the field of intellectual capital.
\end{abstract}

Keywords: intellectual capital; Irish ICT sector; management accounting systems; performance. 
Reference to this paper should be made as follows: Cleary, P., Kennedy, T., O'Donnell, D., O’Regan, P. and Bontis, N. (2007) 'Positioning management accounting on the intellectual capital agenda', Int. J. Accounting, Auditing and Performance Evaluation, Vol. 4, Nos. 4/5, pp.336-359.

Biographical notes: Peter Cleary lectures in Management Accounting at University College Cork, Ireland. A qualified accountant, he has recently completed his $\mathrm{PhD}$ thesis on the relationship between management accounting and intellectual capital in knowledge intensive firms, one of the first researchers to address this particular relationship. His main research interests and publications are in this area. $\mathrm{He}$ is also exploring the interface between the disciplines of human resource management (HRM) and management accounting.

Tom Kennedy is Professor of Accounting at the University of Limerick in Ireland. As a qualified accountant he spent a number of years in practice with leading Irish and multinational firms before entering academia. His main research interests and publications are in management accounting practice, particularly activity-based costing ( $\mathrm{ABC}$ ), management accounting education, and intellectual capital.

David O'Donnell is an interdisciplinary researcher at the Intellectual Capital Research Institute of Ireland. With a diverse background in practice, science and technology, HR and social philosophy his main research interests are in intellectual capital, critical management studies (CMS), corporate governance, HR, and democracy studies. He has published widely and is particularly interested in applying insights from the Frankfurt School of critical social theory, the work of Jürgen Habermas and others, in collaborative interdisciplinary work.

Philip O'Regan, a qualified accountant, spent over a decade in practice before entering academia. He now lectures in Financial Accounting at the University of Limerick in Ireland where he has won several awards for teaching excellence. $\mathrm{He}$ has authored or co-authored six books and published widely within the disciplines of intellectual capital, corporate governance, financial reporting, accounting history, political history and top management teams

Nick Bontis is an Associate Professor of Strategic Management at the DeGroote School of Business, McMaster University, Canada. He graduated with a PhD from the Ivey Business School, University of Western Ontario. His research interests pertain to intellectual capital, knowledge management, and organisational learning. He has won numerous awards for his research and teaching and is recognised as a world-leading keynote speaker and authority on the topic of intellectual capital and knowledge management. He is also the Program Director for the World Congress on Intellectual Capital and the Director of the Institute for Intellectual Capital Research.

\section{Introduction}

It is now regularly argued that the ability to create, transform and capitalise on knowledge and intangible assets is ultimately what delivers competitive advantage (Arthur, 1996; 
Bontis, 1998, 1999, 2001; Edvinsson, 2002; Eustace, 2000; Foss, 1996; Guthrie et al., 2001; Mouritsen et al., 2001; Nonaka and Takeuchi, 1995; Roos et al., 1997; Serenko and Bontis, 2004; Spender, 1996; Spender and Grant, 1996; Stewart 2002; Sveiby, 1997; Von Krogh et al., 2000). The International Federation of Accountants (IFAC, 1998) endorses this emphasis on knowledge as the primary source of competitive advantage. It follows that management accounting, as both discipline and practice, would be expected to react to such developments by designing and implementing management accounting systems to provide relevant information to guide operations and strategy on the management of intangibles and intellectual capital (IC). This is the focus of this paper.

Accounting for knowledge-based assets or capabilities is now a significant challenge for the vast majority of firms. Research to date in the area of IC has primarily focused on theory generation in an attempt to raise awareness and trigger debate (Marr and Gray, 2002). Now that this objective has, at least to some extent, been achieved, it is time to progress work to the next level of theory testing; otherwise, the entire IC research field may start to lose credibility (Gu and Lev, 2001; Guthrie et al., 2001).

Given the critical role that management accounting plays in providing information to inform managerial decision making, this exploratory paper investigates the extent to which management accounting systems impact upon internal structural capital and business performance. Building on earlier work in the IC field, it develops a theoretical model that captures the type of management accounting systems in use and then both situates and integrates these systems theoretically with the human, internal and relational dimensions of IC. This entailed designing a statistically reliable and pragmatically credible management accounting systems construct. Drawing on perceptual data from Chief Financial Officers (CFOs) in an ICT sector the results on testing the structural model are mixed. They show positive path coefficients between management accounting systems, structural capital and business performance - none of which are statistically significant. The other relationships however, strongly support earlier work (Bontis, 1998; Bontis and Fitz-enz, 2002). Despite the fact that the paths from the management accounting construct are not statistically significant, the findings suggest that management accounting systems can positively impact on the performance of knowledge-intensive firms mediated through their internal structural capital. This paper also affirms the perceived importance of intangible resources to firms operating in a knowledge-intensive sector and highlights the potential role that management accounting can make in the management of IC and performance in such sectors.

The structure of the remainder of the paper is as follows. Section 2 presents a brief review of human resource accounting (HRA), the resource-based literature and the emergence of the knowledge-based view - following which the theoretical model is proposed. Section 3 documents the research method and data sources used. Section 4 presents the main research findings. The paper concludes in Section 5 with a discussion of the results, research limitations and future research possibilities.

\section{Literature review}

In the introduction to the special issue of Accounting, Auditing and Accountability Journal $(A A A J)$ in 2001, James Guthrie, Richard Petty and Ulf Johanson note that: 
"... there is a growing awareness that IC adds significantly to the value of a business, and in some cases, represents almost the entire value base." (2001, p.366)

This strong claim on IC requires some theoretical introduction in the context of situating management accounting within its discourse - in doing so here we draw on HRA, the resource base view (RBV), the knowledge base view (KBV) and a discussion of the more mid-range pragmatic templates that have emerged over the past decade or so.

\subsection{Human resource accounting (HRA)}

Accounting for knowledge-based assets is not in itself an entirely new phenomenon, having previously emerged in the mid 1960s with the work of Hermanson (1964). He employed the term 'human asset accounting' to identify his attempts at bringing people or human capital into formal financial statements, not least the balance sheet where the absence of human assets was a glaring omission (Roslender, 2000). The difficulties involved in 'putting people on the balance sheet' were only one aspect of the second phase in accounting for the human element known as HRA.

HRA has had a minimalist presence in mainstream accounting research since the late 1970s, despite the growing awareness that people, and knowledge, were crucial to the attainment of sustainable competitive advantage by firms (Gröjer and Johanson, 1998; Johanson, 1999; Lynn, 2000; Petty and Guthrie, 2000). The emergence of the internet, the 'dot.com' boom, and galloping market-to-book ratios have all contributed to an invigorated interest in intangible assets, processes and values. From a management accounting perspective, this has manifested itself in a growing concern at the diminishing relevance of traditional management accounting systems (Johanson et al., 2001; Johnson and Kaplan, 1987; Marr and Grey, 2002). Many have argued that in order to regain relevance, formal accounting and management control systems have to be reshaped to take intangible or non-monetary aspects into closer consideration (Canibano et al., 2000; Edvinsson and Malone, 1997; Kaplan and Norton, 1992, 1996a,b; Skoog, 2002; Sveiby, 1997). Most firms, as yet, have neither the requisite methods or tools to use that would enable them to analyse either their IC stocks or their organisational learning flows (Barge et al., 2002; Bontis, 1999).

To remain competitive, organisations need to adopt new ways of thinking about business, not new tools and solutions designed to improve on old practices. Preventing businesses from adopting, or even from understanding the need for, new ways of thinking are the accounting-based performance measures customarily used for operational control purposes. Using this information to control a company's relationships with customers, employees and suppliers may actually trigger behaviour that impairs long-run competitiveness and profitability (Johnson, 1992).

Surveys of both manufacturing and service organisations have found that intangibles are increasingly critical to a company's value (Andriessen and Tissen, 2000; Barskey and Marchant, 2000; Barth, 1998; Leadbeater, 2000; Litman, 2000; Ratnatunga, 2002). Ratnatunga and colleagues (2004) cite a survey from the early 1990 s showing $81 \%$ of large companies reporting no intangible assets in their balance sheets. More recently, Leadbeater (2000) found that $76 \%$ of 226 quoted companies did not record any intangibles on their balance sheet. Research emanating from the UK has found that IC leaders (firms 
who expect the value contributed by IC to their business to grow substantially or significantly over the next five years) appear to be more active in measuring the performance of their IC assets and providing appropriate information to management (Perrin, 2000). Roslender and Fincham (2004, p.202), however, based on case study research in the UK, find 'only limited evidence to suggest that IC, including knowledge management, is presently a major focus of interest' within their sample of firms. Few firms can claim the sophistication of the 'IC Statements' constructed by the Danish firms (Danish Guidelines, 2003; Mouritsen et al., 2001). Mapping this value creating process remains the challenge for the vast majority of firms, and for management accounting.

\subsection{Resource base view (RBV)}

The notion that firms are fundamentally heterogeneous, in terms of their resources, competencies and internal capabilities has long been at the heart of the field of strategic management. Those that are distinctive or superior in comparison to rival firms may become the basis for competitive advantage if they are matched appropriately to environmental opportunities. This resource-based view of the firm (RBV) is a widely used theory of competitive advantage with firms advised to harness their existing resources as well as to actively develop new ones (Amit and Schoemaker, 1993; Collis and Montgomery, 1995; Kay, 1993; Rogers, 2001; Williams 1992). Heretofore, in the economic landscapes of the industrial and agricultural eras, the main sources of economic value were deemed to be tangible in nature. In the 'knowledge' economy, people, and the assets that they bring - creativity, expertise, capabilities, relationships, competencies and innovation - emerge as the dominant economic factor (Pilch, 2000). This is now the basic principle upon which resource-based research continues to build (Barney et al., 2001; Peteraf, 1993; Rogers, 2001). In effect, firms are advised to seek to maximise the returns obtainable from their advantage-creating resources in terms of value, rareness, inimitability and non-substitutability (Amit and Schoemaker, 1993; Barney 1991; Collis and Montgomery, 1995; Dierickx and Cool, 1989; Grant, 1991).

\subsection{Knowledge base view (KBV)}

Since the origin of all tangible resources lies outside the firm, it follows that competitive advantage is more likely to arise from the intangible firm-specific knowledge that enables it to add value to the incoming factors of production in a relatively unique manner. It is the firm's knowledge, its ability to generate knowledge, and its ability to leverage such knowledge into economic and social value that lies at the core of a more epistemologically sound theory of the firm (Blanco et al., 2002; O'Donnell et al., 2003; Spender, 1996). This is where the knowledge-based view (KBV), to the extent that it focuses upon knowledge as the most strategically important of the firms' resources, builds on the resource based view. Its proponents argue that highly firm-specific knowledge-based resources and their combination are the determinants of competitiveness and performance (Leitner and Warden, 2004). However, there is insufficient consensus as to its precepts or purpose, let alone its analysis and predictions, for it to be fully recognised as a 'theory'. The debate to date represents a confluence of long-established interests in uncertainty and information (Grant, 1996) with several streams of newer thinking on a knowledge based theory of the firm in emergence. 
Those who have explored the positioning of the resource-based view relative to neo-classical microeconomics have focused their efforts on describing and measuring the attributes of resources and capabilities that lead them to be inelastic in supply. Empirically, numerous studies have attempted to measure these attributes of a firm's resources and capabilities, and then to correlate these measures with business performance (Makadok, 1999; Robins and Wiersema, 1995). Overall, this work suggests that firms that build their strategies on path dependent, causally ambiguous, socially complex, and intangible assets outperform those firms that build their strategies solely on tangible assets (Barney, 2001). In sum, what the extant literature on HRA, RBV and KBV advises is that firms should develop strategies, systems and processes for managing both their tangible and intangible resources.

\subsection{Towards a theoretical model}

The identification, management and measurement of tangible resources have traditionally resided within the realm of functional departments such as finance, operations, engineering and management accounting. Highly sophisticated control, appraisal and decision-making models were developed by such disciplines. The increasing relevance of intangibles, however, poses profound challenges as noted above. Disciplines such as management accounting have responded with a research focus that has tended to concentrate primarily on the control aspects of both managerial decision making and performance. This narrow 'responsibility accounting' orientation has been at the heart of the 'lost relevance' and 'evolution versus revolution' debates (Bromwich and Bhimani, 1989, 1994; Johnson and Kaplan, 1987; Lev, 1997). The balanced scorecard has emerged as one attempt to regain this lost relevance (Kaplan and Norton, 1992, 1996a,b). However, little progress has been made in arriving at a 'standard' set of performance measures for the human asset and IC resources of the organisation (Bontis, 2001; Bontis et al., 1999; Brennan and Connell, 2000; Innes and Vedd, 1998).

Notwithstanding this vacuum, various pragmatic templates for recognising, measuring and managing intangible assets have emerged. These aim to somehow conceptualise the "dynamic process of situated collective knowing that is capable of being leveraged into economic and social value" (O’Donnell et al., 2003, p.84). Within these templates, a pragmatic consensus has emerged in which IC is heuristically viewed as consisting of human, structural and relational dimensions and the complex set of relationships between them (Andriessen, 2004; Bontis, 1996, 1998, 1999, 2001; Edvinsson and Sullivan, 1996; O'Donnell and O'Regan, 2000; Roos et al., 1997; Saint-Onge, 1996; Stewart, 1997; Sveiby, 1997; Von Krogh and Roos, 1996). Company value is conceptualised as a combination of financial capital on the one hand and IC, as heuristically constituted by these three dimensions, on the other. These templates are complemented by various techniques such as market-to-book ratios, Tobin's $q$ and other industry-specific models. While yet to be fully tested, they provide a common base that allows at least some aspects of business performance to be benchmarked and some comparative measures of IC to be established (Dzinkowski, 2000; O'Regan et al., 2001).

However, the daunting challenge to develop a model that will meet the test of generally accepted accounting principles (GAAP) for external reporting, in the context of the transition to International Financial Reporting Standards, is not realistic at this time. 
Less constraining is the need to develop a generalist model that can be crafted and used for internal purposes. The seminal work of Karl-Erik Sveiby, Leif Edvinsson and the Danish Guidelines provide a solid foundation from which to position this paper. This study explicitly focuses on the firm's management accounting systems in reporting internally on its repository of value-creating assets. This begs the key question of how and where to position management accounting within such a generalist IC model.

A number of researchers in this area have already begun to move away from theorising about IC research to attempting to better understand the set of relationships that it encapsulates. Bontis (Bontis, 1998; Bontis and Fitz-enz, 2002; Bontis et al., 2000), for example, was one of the earliest researchers to develop a conceptual causal model that explored the relationship between the three heuristic dimensions of IC (human, relational and structural) and business performance (see Figure 1).

His results suggest that IC has a significant and substantive impact on business performance; and he concluded that this relationship was likely to be industry specific. This work is the methodological starting point adopted for this paper in that we pragmatically position management accounting systems as influencing the internal structural capital of the firm (see Figure 2). Roberts' (2003) viewpoint broadly supports this positioning as he suggests that accounting, as a rules-based management technology, comprises a natural element of structural capital. One would therefore expect a sophisticated management accounting department to be actively identifying and reporting on the firm's value-creating assets, including its intangible assets. Perceptions on IC value were requested by replicating the basic format from O'Donnell and O'Regan (2000). Measures for human capital, structural capital, relational capital and performance were replicated from Bontis and Fitz-enz (2002). The management accounting systems construct is original.

\section{Research method and data}

A lack of empirical data has been the primary constraint in attempting to further our understanding of IC and intangible values (Marr and Gray, 2002). Focusing upon privately owned indigenous firms operating within the Irish Information and Communications Technology (ICT) sector, this study involved the collection of data from CFOs. This sector was chosen because it is fast growing, highly volatile, and assumed to be rich in IC.

The research instrument used was a questionnaire. The management accounting issues addressed in the questionnaire were identified following a literature review and a focus group session. The initial instrument was piloted with a group of CFOs to elicit responses as to suitability and relevance, with the questionnaire revised accordingly. Drawing on the extant management accounting literature, it was decided to include 15 items on different management accounting systems (see Table 1). A key purpose was to identify the management accounting systems in use in this sector and their levels of usage. 
Figure 1 Intellectual capital and performance

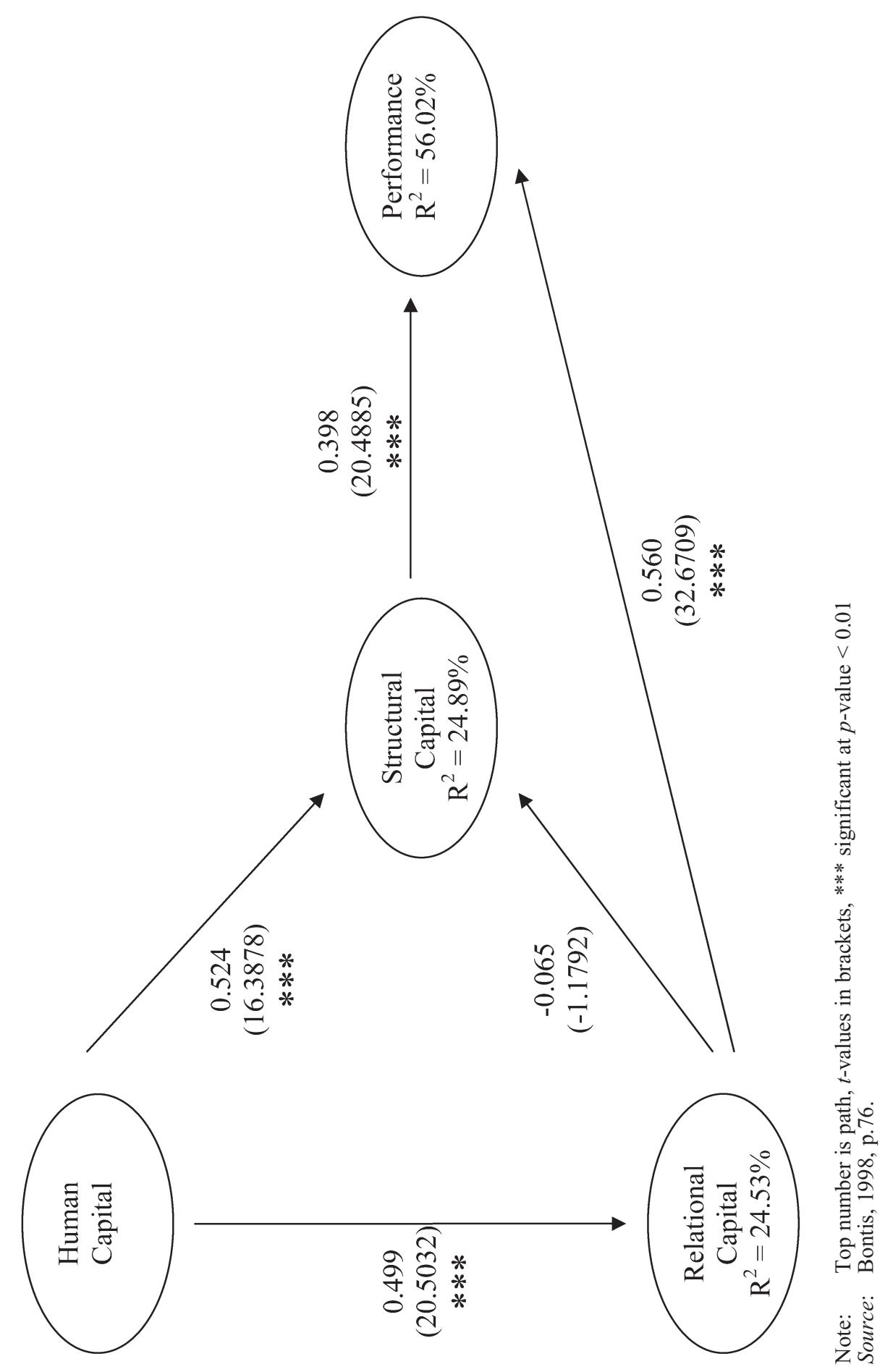


Figure 2 Conceptual model

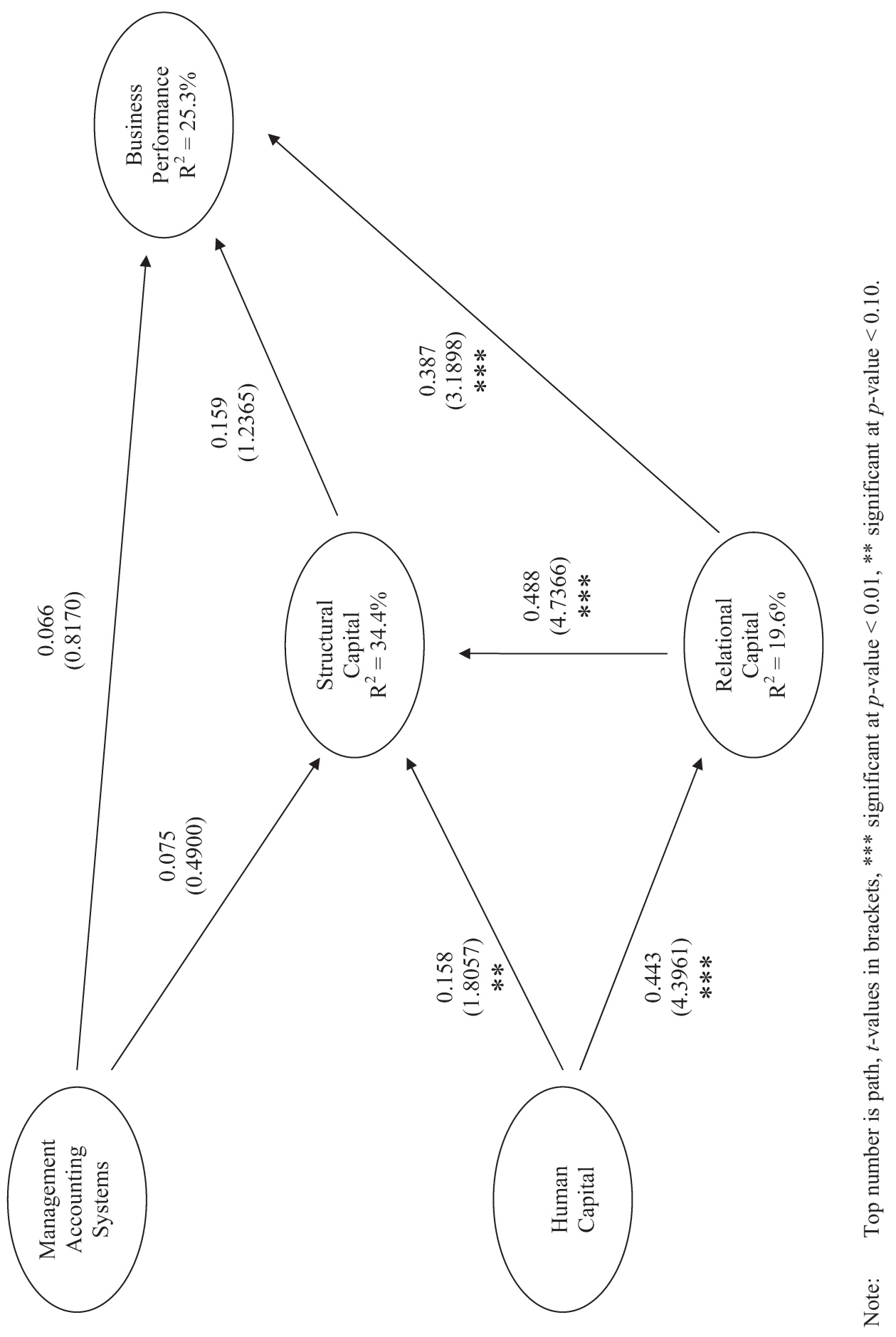


Table 1 Level of usage of management accounting systems (MAS)

\begin{tabular}{lllr}
\hline Item & Description & Mean* & Ranking \\
\hline MAS1 & Standard costing/variance analysis & 3.9659 & 2 \\
MAS2 & Absorption (full) costing & 2.3295 & 8 \\
MAS3 & Variable costing & 2.9432 & 4 \\
MAS4 & Activity-based costing/management & 2.9773 & 3 \\
MAS5 & Balanced scorecard & 1.9205 & 10 \\
MAS6 & Target costing & 2.2955 & 9 \\
MAS7 & Job costing & 4.5795 & 1 \\
MAS8 & Process costing & 2.3750 & 7 \\
MAS9 & Life-cycle costing & 1.8295 & 11 \\
MAS10 & Through-put accounting & 1.7273 & 13 \\
MAS11 & Backflush costing & 1.3636 & 15 \\
MAS12 & Functionality costing & 1.7386 & 12 \\
MAS13 & MRP/ERP/EVA/SVA & 1.7273 & 13 \\
MAS14 & Strategic management accounting & 2.9205 & 5 \\
MAS15 & Transfer pricing models & 2.6364 & 6
\end{tabular}

Notes: * Scale from 1 to 7 , where $1=$ no usage and $7=$ very high usage.

Utilising a variety of information sources, 385 ICT firms with at least 10 full-time employees were identified as the appropriate sample frame. Each of their CFOs, or most senior financial executive, was identified and subsequently posted a copy of the questionnaire along with supporting documentation, signed assurances on confidentiality and pre-paid response envelopes. Follow-up letters, telephone calls and emails were used to enhance response rates with those who had not responded after three weeks. The first mailing took place in mid June 2001 and the process concluded in early November 2001. A usable response rate of slightly less than $23 \%$ was achieved, representing 88 completed questionnaires, which can be considered reasonable when compared with recent surveys of similar proportions (Beattie and Pratt, 2003).

\subsection{Bias}

The use of survey data raises the potential for the existence of bias. Non-response bias was evaluated by comparing the number of employees of firms that participated in the study with the remainder of the sample frame (Oppenheim, 1966, p.34). Using SPSS (Version 11), there was no statistical difference between those firms that participated in the study and those that did not in terms of employee numbers $(t=-1.078, p>0.01)$. Participating firms had an average of slightly less than 52 employees while whose firms that did not respond had an average of just over 61 employees. Temporal bias was evaluated by comparing the first 44 firms that completed the questionnaire against the second 44 firms on the basis of: 
- number of employees

- response to the perceptual business performance item 'our organisation regularly meets its business goals'.

No statistical difference was found in terms of employee numbers $(t=0.186, p>0.01)$, with the former 44 firms reporting an average of just less than 53 and the latter 44 firms reporting an average of just over 50 employees. In terms of business performance no statistical difference was found $(t=-0.327, p>0.01)$. The mean response, on a 7 -point Likert scale, for the first 44 firms was 4.82 versus 4.91 for the second 44 firms. Therefore, it is reasonable to conclude that the integrity of the data is not adversely affected by the existence of bias.

\subsection{Measurement and structural model}

A structural equation modelling (SEM) technique, partial least squares (PLS) using PLS-Graph (Version-3), was used to test the conceptual model. This methodology has been used in previous IC research (Bart and Bontis, 2003; Bontis, 1998, 2004; Bontis and Fitz-enz, 2002; Bontis et al., 2000, 2002; Ordonez De Pablos, 2002). PLS is similar to LISREL and other covariance structure analysis (CSA) structural equation modelling techniques in that it combines data and theory to simultaneously estimate paths and loadings. However, unlike other techniques, it attempts to maximise the variance explained in a model's endogenous constructs. One of its key benefits as a technique is that it works well with smaller samples. It is also better suited to more exploratory research contexts (Chin, 1997) as is the case with this particular study.

While some researchers argue for the largest possible sample size at the risk of increasing non-sampling errors, others argue for a statistical calculation of the necessary sample size. This study represents an achieved sample size of 88 respondents. According to PLS procedures, in general, the most complex model will involve:

(i) the indicators on the most complex formative construct

(ii) the largest number of antecedent constructs leading to an endogenous construct.

Sample size requirements become at least 10 times the number of predictors from (i) or (ii), whichever is greater (Barclay et al., 1995). In this case, the final model resulted in no formative constructs and four antecedent constructs. Therefore, the minimum required sample size in this case is 40 .

The first step was to explicitly specify both the structural (or path) model and the construct-to-measures relationships in the measurement model. The measurement and structural parameters were then estimated in an iterative fashion using traditional Ordinary Least Squares (OLS) simple and multiple regressions. This process continued until the difference between the consecutive iterations for the stop criterion selected was extremely small. As a final step, the simple regression coefficient between the component scores was calculated (Barclay et al., 1995).

Although the measurement and structural parameters are estimated together, a PLS model is analysed and interpreted in two stages:

- the assessment of the reliability and validity of the measurement model

- the assessment of the structural model. 
This sequence ensures that one has reliable and valid constructs before attempting to draw conclusions regarding the nature of the relationship between them (Barclay et al., 1995; Hulland, 1999).

The measurement model was assessed by examining for:

- individual item reliability (Table 2)

- matrix of loadings and cross-loadings (Table 3)

- convergent validity/internal consistency (Table 4)

- discriminant validity (Table 5).

Individual item reliability was assessed by examining the loadings, or simple correlations, of the measures with their respective constructs. A rule of thumb is to accept items with loadings of 0.70 or more which implies more shared variance between the construct and its measures than error variance. Since loadings are correlations, this implies that more than $50 \%$ of the variance in the observed variable is shared with the construct (Barclay et al., 1995). The one departure from this threshold occurred in the pursuit of a pragmatically credible management accounting systems construct (MAS) where a loading of 0.5 is deemed acceptable.

Initial attempts at extracting a statistically distinct MAS construct from the 15 MAS items using factor analysis were not encouraging as they failed to include management accounting systems with high levels of usage. In the interests of face validity and pragmatic relevance it was then decided to exclude management accounting system items with an average mean response of less than 2.0 (see Tables 1 and 2) from further analysis due to their low usage levels ( $1=$ no usage; $7=$ very high usage). Consequently, the following six items were excluded; MAS5 - balanced scorecard, MAS9 - life-cycle costing, MAS10 - through-put accounting, MAS11 - backflush costing, MAS12 - functionality costing and MAS13 - MRP/ERP/EVA/SVA. Those remaining MAS items with loadings of greater than 0.50 were then deemed to be acceptable due to the exploratory nature of the research on management accounting being undertaken. This approach is consistent with Hulland (1999) who argued that items with loadings of less than 0.40 (a threshold commonly used for factor analysis results) or 0.50 should be disregarded from further statistical analysis. Strict adherence to this 0.50 threshold resulted in the removal of item MAS15 - Transfer Pricing Models from further statistical analysis owing to its 0.495 loading result. Item MAS14 - Strategic Managerial Accounting, was also removed from the final management accounting systems construct, as despite loading onto the MAS construct at 0.581 , it loaded at a higher rate on an alternative management accounting systems factor concurrently. The final, if more parsimonious, seven item construct arrived at in this manner has face, statistical and, perhaps more importantly, pragmatic validity and is the MAS construct utilised in testing the structural PLS model presented in Figure 2. 
Table 2 Individual item reliability test

\begin{tabular}{|c|c|c|c|c|}
\hline & Mean & Standard deviation & Item loading & Item to construct \\
\hline \multicolumn{5}{|l|}{ HumCap* } \\
\hline HumCap1 & 4.8182 & 1.2181 & 0.721 & 0.6407 \\
\hline HumCap2 & 5.2841 & 1.0051 & 0.807 & 0.7186 \\
\hline HumCap3 & 4.8295 & 1.3410 & 0.553 & removed \\
\hline HumCap4 & 5.4886 & 1.0283 & 0.776 & 0.6739 \\
\hline HumCap5 & 5.7216 & 0.9434 & 0.806 & 0.7051 \\
\hline HumCap6 & 5.9375 & 0.8637 & 0.874 & 0.7890 \\
\hline HumCap7 & 5.8352 & 0.9460 & 0.816 & 0.7264 \\
\hline \multicolumn{5}{|l|}{$M A S$} \\
\hline MAS1 & 3.9659 & 2.1413 & 0.676 & 0.5678 \\
\hline MAS2 & 2.3295 & 1.8240 & 0.687 & 0.5651 \\
\hline MAS3 & 2.9432 & 1.8776 & 0.783 & 0.6665 \\
\hline MAS4 & 2.9773 & 2.0056 & 0.726 & 0.5985 \\
\hline MAS5 & 1.9205 & 1.5627 & removed & removed \\
\hline MAS6 & 2.2955 & 1.8204 & 0.575 & 0.4324 \\
\hline MAS7 & 4.5795 & 2.1588 & 0.564 & 0.4977 \\
\hline MAS8 & 2.3750 & 1.8651 & 0.766 & 0.6693 \\
\hline MAS9 & 1.8295 & 1.3237 & removed & removed \\
\hline MAS10 & 1.7273 & 1.4201 & removed & removed \\
\hline MAS11 & 1.3636 & 1.0415 & removed & removed \\
\hline MAS12 & 1.7386 & 1.3261 & removed & removed \\
\hline MAS13 & 1.7273 & 1.1912 & removed & removed \\
\hline MAS14 & 2.9205 & 1.9723 & 0.581 & removed \\
\hline MAS15 & 2.6364 & 1.9009 & 0.495 & removed \\
\hline \multicolumn{5}{|l|}{ StrCap* } \\
\hline StrCap1 & 5.7159 & 1.0928 & 0.797 & 0.6408 \\
\hline StrCap2 & 5.0227 & 1.4698 & 0.868 & 0.7698 \\
\hline StrCap3 & 5.1818 & 1.3775 & 0.864 & 0.7922 \\
\hline StrCap4 & 6.0341 & 0.9401 & 0.653 & removed \\
\hline StrCap5 & 4.8977 & 1.3394 & 0.787 & 0.6589 \\
\hline \multicolumn{5}{|l|}{ RelCap* } \\
\hline RelCap1 & 4.9545 & 1.2121 & 0.767 & 0.6394 \\
\hline RelCap2 & 4.2614 & 1.3347 & 0.700 & 0.5361 \\
\hline RelCap3 & 4.4545 & 1.4693 & 0.863 & 0.7391 \\
\hline RelCap4 & 4.1591 & 1.4691 & 0.824 & 0.6595 \\
\hline RelCap5 & 4.2273 & 1.4679 & 0.630 & removed \\
\hline \multicolumn{5}{|l|}{ BusPer* } \\
\hline BusPer1 & 4.8636 & 1.2971 & 0.837 & 0.7874 \\
\hline BusPer2 & 4.2614 & 1.4101 & 0.875 & 0.8365 \\
\hline BusPer3 & 4.1364 & 1.4478 & 0.853 & 0.7921 \\
\hline BusPer4 & 5.6023 & 1.1401 & 0.783 & 0.6105 \\
\hline BusPer5 & 4.9773 & 1.4698 & 0.817 & 0.7111 \\
\hline BusPer6 & 5.9091 & 1.0016 & 0.677 & removed \\
\hline
\end{tabular}

Notes: $*$ Mean scale from 1 to 7 , where $1=$ strongly disagree and $7=$ strongly agree. 
Table 3 Individual item matrix of loadings and cross-loadings test

\begin{tabular}{|c|c|c|c|c|c|}
\hline & HumCap & $M A S$ & StrCap & RelCap & BusPer \\
\hline HumCap1 & 0.723 & 0.127 & 0.376 & 0.489 & 0.418 \\
\hline HumCap2 & 0.803 & 0.258 & 0.320 & 0.347 & 0.322 \\
\hline HumCap3 & 0.554 & 0.085 & 0.127 & 0.032 & 0.119 \\
\hline HumCap4 & 0.775 & 0.249 & 0.225 & 0.251 & 0.378 \\
\hline HumCap5 & 0.807 & 0.179 & 0.415 & 0.383 & 0.484 \\
\hline HumCap6 & 0.874 & 0.170 & 0.414 & 0.357 & 0.484 \\
\hline HumCap7 & 0.816 & 0.224 & 0.378 & 0.314 & 0.491 \\
\hline MAS1 & -0.097 & 0.543 & 0.095 & 0.111 & 0.037 \\
\hline MAS2 & 0.066 & 0.640 & 0.028 & -0.013 & -0.059 \\
\hline MAS3 & 0.030 & 0.685 & 0.082 & 0.113 & 0.017 \\
\hline MAS4 & 0.119 & 0.620 & 0.130 & 0.098 & 0.064 \\
\hline MAS5 & 0.108 & 0.683 & 0.148 & 0.123 & 0.218 \\
\hline MAS6 & -0.117 & 0.665 & 0.013 & 0.000 & 0.009 \\
\hline MAS7 & 0.042 & 0.425 & 0.030 & -0.106 & -0.065 \\
\hline MAS8 & 0.092 & 0.767 & 0.121 & -0.003 & 0.163 \\
\hline MAS9 & -0.050 & 0.643 & 0.081 & -0.080 & 0.102 \\
\hline MAS10 & -0.018 & 0.841 & 0.129 & 0.067 & 0.206 \\
\hline MAS11 & 0.077 & 0.804 & 0.160 & 0.142 & 0.236 \\
\hline MAS12 & 0.054 & 0.838 & 0.188 & 0.152 & 0.271 \\
\hline MAS13 & 0.051 & 0.532 & 0.171 & 0.163 & 0.084 \\
\hline MAS14 & 0.207 & 0.570 & 0.282 & 0.373 & 0.236 \\
\hline MAS15 & 0.013 & 0.515 & 0.250 & 0.197 & 0.129 \\
\hline StrCap1 & 0.343 & 0.140 & 0.797 & 0.376 & 0.379 \\
\hline StrCap2 & 0.383 & 0.175 & 0.868 & 0.472 & 0.261 \\
\hline StrCap3 & 0.336 & 0.090 & 0.864 & 0.506 & 0.319 \\
\hline StrCap4 & 0.393 & 0.139 & 0.653 & 0.343 & 0.452 \\
\hline StrCap5 & 0.389 & 0.218 & 0.787 & 0.522 & 0.364 \\
\hline RelCap1 & 0.421 & 0.033 & 0.533 & 0.767 & 0.471 \\
\hline RelCap2 & 0.239 & 0.211 & 0.396 & 0.700 & 0.380 \\
\hline RelCap3 & 0.212 & 0.033 & 0.501 & 0.863 & 0.380 \\
\hline RelCap4 & 0.269 & 0.100 & 0.387 & 0.824 & 0.339 \\
\hline RelCap5 & 0.195 & 0.161 & 0.298 & 0.630 & 0.342 \\
\hline BusPer1 & 0.364 & 0.113 & 0.371 & 0.378 & 0.837 \\
\hline BusPer2 & 0.346 & 0.145 & 0.384 & 0.423 & 0.875 \\
\hline BusPer3 & 0.312 & 0.158 & 0.311 & 0.451 & 0.853 \\
\hline BusPer4 & 0.348 & 0.165 & 0.373 & 0.427 & 0.783 \\
\hline BusPer5 & 0.335 & 0.100 & 0.331 & 0.386 & 0.817 \\
\hline BusPer6 & 0.408 & 0.212 & 0.354 & 0.363 & 0.677 \\
\hline
\end{tabular}

Note: Bold values in diagonals are greater than values in corresponding columns. 
Table 4 Construct internal consistency and convergent validity tests

\begin{tabular}{|c|c|c|c|}
\hline & \multicolumn{2}{|c|}{ Internal consistency } & \multirow{2}{*}{$\begin{array}{c}\frac{\text { Convergent validity }}{>0.5} \\
\text { Fornell and Larcker }\end{array}$} \\
\hline & $\begin{array}{l}>0.7 \\
\text { Alpha }\end{array}$ & $\begin{array}{l}\qquad>0.7 \\
\text { Fornell and Larcker }\end{array}$ & \\
\hline HumCap & 0.8862 & 0.9147 & 0.6421 \\
\hline MAS & 0.8246 & 0.8606 & 0.4721 \\
\hline StrCap & 0.8623 & 0.8983 & 0.6886 \\
\hline RelCap & 0.8183 & 0.8691 & 0.6255 \\
\hline BusPer & 0.8964 & 0.9192 & 0.6949 \\
\hline
\end{tabular}

Table 5 Construct discriminant validity test

\begin{tabular}{llllll}
\hline & \multicolumn{5}{c}{$\begin{array}{c}\text { Discriminant validity } \\
\text { Correlation of constructs }\end{array}$} \\
& HumCap & MAS & StrCap & RelCap & BusPer \\
\hline HumCap & $\mathbf{0 . 8 0 1}$ & & & & \\
MAS & 0.141 & $\mathbf{0 . 6 8 7}$ & & & \\
StrCap & 0.368 & 0.101 & $\mathbf{0 . 8 3 0}$ & $\mathbf{0 . 7 9 1}$ & \\
RelCap & 0.430 & 0.018 & 0.551 & 0.465 & $\mathbf{0 . 8 3 4}$ \\
BusPer & 0.480 & 0.017 & 0.371 & & \\
\hline
\end{tabular}

Note: Bold values in diagonals are greater than values in corresponding rows or columns.

As Table 2 illustrates, apart from the management accounting items discussed above, four other items (one each from the human capital, structural capital, relational capital and business performance constructs) did not load to the requisite individual item reliability threshold of 0.70 and were also removed from further analysis. The appropriateness of each of the remaining items in each construct was then confirmed by testing the item-to-construct correlation for each measure. It was found that all the remaining measures exceeded the threshold of 0.35 as suggested by Saxe and Weitz (1982) for this particular test.

A matrix of loadings of cross-loadings was then produced to test each item's discriminant validity (Table 3 ). To evaluate this, one compares the loading of an item with its associated construct to its cross-loadings. All remaining items had higher loadings with their corresponding factors when compared to their cross-loadings. This confirms that each of the items used has adequate discriminant validity.

As regards construct internal consistency, researchers employing PLS generally use the measure developed by Fornell and Larcker (1981). This is computed as the sum of the loadings, all squared, divided by the sum of the loadings, all squared, plus the sum of the error terms. This measure is similar to Cronbach's alpha as a measure of internal consistency except that the latter presumes, a priori, that each indicator of a construct contributes equally (that is, the loadings are set equal to unity). Nevertheless, the interpretation of the values obtained is similar, and the guidelines offered by Nunnally (1978) can be adopted. These suggest 0.70 as a benchmark for 'modest' reliability applicable in research of an exploratory nature (Barclay et al., 1995). Fornell and Larcker (1981) support an average variance extracted above 50\%. 
The results in Table 4 demonstrate that each construct has adequate internal consistency by exceeding the 0.70 threshold for both the Cronbach's alpha and Fornell and Larcker measures. With regards to convergent validity, all constructs apart from Management Accounting Systems (0.4721) reached the 50\% threshold as proposed by Fornell and Larcker. However, its exploratory nature combined with the fact that this particular construct has met and exceeded all other statistical tests, renders this as acceptable.

Discriminant validity at the construct level indicates the extent to which a given construct differs from other constructs. In a PLS analysis, one criteria for adequate discriminant validity is that a construct should share more variance with its measures than it shares with other constructs in a model. In order to assess discriminant validity, Fornell and Larcker (1981) suggest the use of the measure Average Variance Extracted (AVE) (that is, the average variance shared between a construct and its measures). This measure should be greater than the variance shared between the construct and other constructs in the model (that is, the squared correlation between two constructs). The square root of the AVE is illustrated as the diagonal of the correlation of constructs matrix where each should be greater than the off-diagonal elements in the corresponding rows and columns (Barclay et al., 1995); and the results in Table 5 confirm this to be the case here.

\section{Findings and discussion}

Conceptual models in PLS include both the measurement model for each construct and the structural model (interrelationships amongst constructs). Having confirmed the reliability and validity of the measurement model noted above, the next stage in PLS modelling is to assess the structural model (Barclay et al., 1995; Hulland, 1999). In order to achieve this, PLS calculates indirect and total (direct and indirect) effects to establish the relative importance of antecedent constructs. This is an advantage over traditional path analysis where effects need to be calculated by hand. A measure of the predictive power of a model is the $R^{2}$ value for the endogeneous constructs (see Figure 2). These values should be interpreted in the same manner as the $R^{2}$ obtained in the multiple regression analysis; that is, it indicates the amount of variance in the construct which is explained by the model (Barclay et al., 1995). The structural model investigating the nature of the relationship between management accounting, IC dimensions and business performance was tested using PLS-GRAPH Version 3 developed by Wynne Chin.

The overall findings presented in Figure 2 are mixed - there is strong statistical support for the original relationships proposed by Bontis (1998), and weak statistical support for the positioning of management accounting systems in relation to both structural capital and business performance. In terms of management accounting, the results show a positive path coefficient of $\beta=0.075(t=0.4900)$ between management accounting systems (MAS) and structural capital, and a positive path coefficient of $\beta=$ $0.159(t=1.2365)$ between structural capital and business performance. Both paths are positive, as theoretically proposed, but are not statistically significant. Further, the direct path between management accounting systems (MAS) and business performance is positive ( $\beta=0.066 ; t=0.8170$ ), but again, is not statistically significant. These initial exploratory findings lend some support to the view that management accounting can impact positively on the performance of knowledge-intensive firms through the mediating effect of its structural capital. 
Further analysis of the management accounting systems in use (see Table 2) adds more credence to the validity of the 'US lost relevance' debate (Johnson and Kaplan 1987) rather than the 'UK Management Accounting: Pathways to Progress' (Bromwich and Bhimani, 1994) perspective. This study found that the majority of firms analysed continued to use traditional cost/control systems such as job costing and standard costing for their management information needs. Contemporary management accounting systems, such as the balanced scorecard, functionality costing, EVA, SVA and ERP systems were excluded, due to their low application levels or, in the case of strategic management accounting, due to a failure to meet the statistical requirements of the final management accounting construct used in the model. On a more positive note, the use of ABC/ABM was much higher than comparative surveys (Innes and Mitchell, 1995, 1997; Innes et al., 2000) and its positive impact on business performance (Kennedy and Affleck-Graves, 2001) contributes to the overall positive path coefficients reported.

These results suggest that the indigenous Irish firms operating within the ICT sector, by virtue of their heavy dependence on traditional cost/control accounting systems, may be missing out on opportunities to leverage their true competitive advantage. Perhaps the views expressed by Lord (1996) are still valid today. He stated that many accountants experience difficulty in coming to terms with 'simple and soft numbers' and posited the view that the widely touted 'strategic management accountant' is but a figment of academic imagination. This could explain the heavy reliance on traditional management accounting systems and the resultant orientation towards the operational rather than the strategic. Given the increasingly intense global economic environment a re-orientation towards information systems that would enhance strategic decision making is suggested by the findings here.

On a further positive note, the results of this study are consistent with Bontis (1998) in most respects (see Figure 2). As with his findings, positive and statistically significant path coefficients were found to exist between human capital and relational capital $\beta=0.443$ $(t=4.3961, p<0.01)$, human capital and structural capital $\beta=0.158(t=1.8057, p<0.10)$ and between relational capital and business performance $\beta=0.387(t=3.1898, p<0.01)$. However, in contrast to his findings, a positive and significant path coefficient was found to exist in this study between relational capital and structural capital $\beta=0.488(t=4.7366$, $p<0.01$ ), while the path coefficient between structural capital and business performance although positive is not statistically significant $\beta=0.159(t=1.2365)$. Finally, the $R^{2}$ or predictive power of each of the exogenous constructs in the conceptual model is as follows: structural capital $34.4 \%$, relational capital $19.6 \%$ and business performance $25.3 \%$, indicating the amount of variance in each construct that is explained by the model. It is important to note that the measure of business performance used here is a perceptual one. Bontis and his colleagues (2000) note, however, that perceived measures of business performance can be a reasonable substitute for objective measures (Dess and Robinson, 1984) and have a significant correlation with objective measures of financial performance (Hansen and Wernerfelt, 1989).

These CFOs perceive that, on average, $57 \%$ of the value of their firms is directly attributable to IC confirming the growing realisation of the importance of IC in knowledge-driven economies (Backhuijs et al., 1999; Bontis, 2003; Edvinsson and Sullivan, 1996; Graham and Pizzo, 1998). This adds momentum to the search for a conceptual framework that brings management accounting systems into IC measurement and management. Further, these CFOs perceive that approximately half of this intangible 
value derives directly from the human capital dimension, with the other $50 \%$ more or less equally divided between structural and relational capital. These findings, based on replicating the basic template used by O'Donnell and O'Regan (2000), support earlier work on this particular data (O'Regan et al., 2001) and on the Irish ICT sector generally (O'Donnell et al., 2003). These perceptions, and the positive and statistically significant paths from human capital in Figure 2, suggest that investment appraisal and other control and decision-making techniques must revisit the traditional view of people as costs (Bontis, 1998, 1999, 2001: Olsson, 1999; O’Regan et al, 2001). The challenge to recognise human capital in financial statements is even more ambitious due to the range of judgemental issues surrounding valuation levels (Roslender, 1997; Roslender and Dyson, 1992; Turner, 1996). Most studies on how users make decisions using human capital measurement information since the early days of HRA have met with limited success (Bassi et al., 2000; Dozentin et al., 1989; Kasper-Fuehrer and Ashkanasy, 2001; Raghurum et al., 2001).

\section{Conclusions}

Although the RBV of the firm advocates the effective management of the entire range of resources at a firm's disposal, the extant accounting framework provides little guidance in understanding and managing the firm's intangible or intellectual resources and their effects on value creation. This study of a sample of Irish ICT firms found that there was no concerted or comprehensive attempt to measure or monitor the IC component of firm value, notwithstanding the fact that CFOs readily recognise its importance as constituting almost $60 \%$ of firm value.

As the management accounting construct that was developed makes clear, these firms continued to rely largely on traditional financial performance indicators and budgetary control to manage their business activities. These were supplemented to a moderate extent by ad hoc information from sources other than mainstream cost accounting systems. This is consistent with Bukh et al. (2002), Low (2002), Peppard and Rylander (2001), Pilch (2000) and Roslender and Fincham (2001) who note that firms continue to attempt to measure the assets of the creative economy with the tools of a manufacturing based economy. Unless processes and procedures are put in place to identify, manage and leverage such creative assets and processes, firms are likely to jeopardise their future prospects for survival, prosperity and growth. Firms can no longer rely on reporting of their past and current financial performance in accounting terms, as they are missing both the strategic and knowledge-based perspectives on how to improve both their operating and market-based performance. As global trading conditions continue to become increasingly competitive and fraught with uncertainty, firms will be forced to seek new ways of adding value to their products and services in order to stay competitive.

Given that knowledge management is the raison d'etre of accounting, the challenge for the management accounting system is how to turn this comparative advantage into competitive advantage. Accountants in this sector are already struggling to keep up with and come to terms with e-business (O'Donnell et al., 2004). The transition from cost accounting to management accounting shifted the emphasis from record keeping to 'people'. However, further evolution is necessary as the central theme of that transition was 'responsibility accounting' and the application of the 'controllability principle'. 
Perhaps the Japanese orientation of using management accounting as an information service rather than a definitive set of quantitative techniques is a good basis on which to continue the transition in the context of the contemporary knowledge economy. It might also go some way towards addressing the preparer-user perception gap reported by Pierce and O'Dea (2003) and help to complete the transformation of the management accountant from bean-counter to business partner, both in reality and title.

Given the exploratory nature of this study, there are some important limitations to be noted. The conceptual model needs to be more fully defined and, given the diversity of knowledge constructs, additional measures need to be identified and tested. In terms of future research activity, it would be interesting to extend the scope of this study to include its value relevance for internal decision making purposes. The question of whether the management of these firms are adequately informed by current reporting practice or use some other mechanisms, formal or informal, would be worth investigating. Allied to that is the question of whether this issue is of relevance to the other key stakeholders in firms. Given the 'decentering' of information generally and the democratisation of data in most organisations due to technological developments, the challenges now facing the management accounting profession are increasingly complex. Together, they must respond to that challenge positively or as one American social anthropologist Jennifer James (quoted in Keeva, 1998) has stated, "The more society pushes complexity, the more homo sapiens will push back and take back autonomy". There is unquestionably much more that management accounting, and management accountants, can do in this area.

\section{Acknowledgement}

The research underpinning this paper has been facilitated by a grant from The Chartered Institute of Management Accountants (CIMA).

\section{References}

Amit, R. and Schoemaker, P.J. (1993) 'Strategic assets and organisational rent', Strategic Management Journal, Vol. 14, No. 1, pp.33-46.

Andriessen, D. (2004) 'IC valuation and measurement: classifying the state of the art', Journal of Intellectual Capital, Vol. 5 No. 2, pp.230-242.

Andriessen, D. and Tissen, R. (2000) Weightless Weight - Find Your Real Value in a Future of Intangible Assets, London: Pearson Education.

Arthur, W.B. (1996) 'Increasing returns and the New World of business', Harvard Business Review, Vol. 74, No. 4, pp.100-109.

Backhuijs, J.B., Holterman, W.G.M., Oudman, R.S., Overgoor, R.P.M. and Zijlstra, S.M. (1999) 'Reporting on intangible assets', OECD Symposium on Measuring and Reporting of Intellectual Capital, Amsterdam, June 9-11.

Barclay, D., Higgins, C. and Thompson, R. (1995) 'The partial least squares (PLS) approach to causal modeling: personal computer adoption and use as an illustration', Technology Studies, Vol. 2, No. 2, pp.285-309.

Barge, A., Lemus, A. B., Nunez, R., Pacheco, M. and Modrego, A. (2002) 'Technology institutes: how they manage their knowledge?', paper presented at The Transparent Enterprise. The Value of Intangibles Conference, Madrid, Spain.

Barney, J. (1991) 'Firm resources and sustained competitive advantage', Journal of Management, Vol. 17, No. 1, pp.99-120. 
Barney, J. (2001) 'Resource-based theories of competitive advantage: a ten-year retrospective on the resource-based view', Journal of Management, Vol. 27, No. 6, pp.643-650.

Barney, J., Wright, M. and Ketchen Jr, D.J. (2001) 'The resource-based view of the firm: ten years after 1991', Journal of Management, Vol. 27, No. 6, pp.625-641.

Barskey, N.P. and Marchant, G. (2000) 'The most valuable resource-measuring and managing intellectual capital', Strategic Finance, Vol. 81, No. 8, pp.59-62.

Bart, C. and Bontis, N. (2003) 'Distinguishing between the board and management company mission: implications for corporate governance', Journal of Intellectual Capital, Vol. 4, No. 3 , pp.361-381.

Barth, M.E. (1998) 'Brand values and capital market valuation', Working Paper, Graduate School of Business, Stanford University, California.

Bassi, L.J., Lev, B., Low, J., McMurrer, D.P. and Siesfeld, G.A. (2000), 'Measuring corporate investments in human capital' in M.M. Blair and T.A. Kochan (Eds), The New Relationship, Human Capital in the American Corporation, Washington, DC: Brookings Institute, pp.334-382.

Beattie, V. and Pratt, K. (2003) 'Issues concerning web-based business reporting: an analysis of the views of interested parties', The British Accounting Review, Vol. 35, No. 2, pp.155-187.

Blanco, C., Navarro, M. and Pena, I. (2002) 'Influence of knowledge-based intangible resources and alliances on business performance', paper presented at The Transparent Enterprise. The Value of Intangibles Conference, Madrid, Spain.

Bontis, N. (1996) 'There's a price on your head: managing intellectual capital strategically', Ivey Business Journal, Summer, pp.40-47.

Bontis, N. (1998) 'Intellectual capital; an exploratory study that develops measures and models', Management Decision, Vol. 36, No. 2, pp.63-76.

Bontis, N. (1999) 'Managing organizational knowledge by diagnosing intellectual capital: framing and advancing the state of the field', International Journal of Technology Management, Vol. 18, Nos. 5-8, pp.433-462.

Bontis, N. (2001) 'Assessing knowledge assets: a review of the models used to measure intellectual capital', International Journal of Management Reviews, Vol. 3, No. 1, pp.41-60.

Bontis, N. (2003) 'Intellectual capital disclosure in Canadian corporations', Journal of Human Resource Costing and Accounting, Vol. 7, Nos. 1/2, pp.9-20.

Bontis, N. (2004) 'National intellectual capital index', Journal of Intellectual Capital, Vol. 5, No. 1, pp.13-39.

Bontis, N. and Fitz-enz, J. (2002) 'Intellectual capital ROI: a causal map of human capital antecedents and consequents', Journal of Intellectual Capital, Vol. 3, No. 3, pp.223-247.

Bontis, N., Chua, W. and Richardson, S. (2000) 'Intellectual capital and the nature of business in Malaysia', Journal of Intellectual Capital, Vol. 1, No. 1, pp.85-100.

Bontis, N., Crossan, M. and Hulland, J. (2002) 'Managing an organizational learning system by aligning stocks and flows', Journal of Management Studies, Vol. 39, No. 4, pp.437-469.

Bontis, N., Dragonetti, N., Jacobsen, K. and Roos, G. (1999) 'The knowledge toolbox: a review of the tools available to measure and manage intangible resources', European Management Journal, Vol. 17, No. 4, pp.391-402.

Brennan, N. and Connell, B. (2000) 'Intellectual capital: current issues and policy implications', Journal of Intellectual Capital, Vol. 1, No. 3, pp.206-240.

Bromwich, M. and Bhimani, A. (1989) Management Accounting: Evolution not Revolution, London: Chartered Institute of Management Accountants.

Bromwich, M. and Bhimani, A. (1994) Management Accounting: Pathways to Progress, London: Chartered Institute of Management Accountants.

Bukh, P.N., Johansen, M.R., Meca, E.G. and Mouritsen, J. (2002) 'IPO Prospectuses as intellectual capital reports: a comparison of danish and spanish reporting practices', paper presented the 25th European Accounting Association (EAA) Annual Congress, Copenhagen, Denmark. 
Canibano, L., Garcia-Ayuso, M. and Sanchez, P. (2000) 'Accounting for intangibles: a literature review', Journal of Accounting Literature, Vol. 19, pp.102-130.

Chin, W. (1997) 'Overview of the PLS Method', available at: http://disc-nt.cba.uh.edu/chin/ plsintro.htm.

Collis, D.J. and Montgomery, C.A. (1995) 'Competing on Resources', Harvard Business Review, Vol. 73, No. 4, pp.118-128.

Danish Guidelines (2003) Intellectual Capital Statements - The New Guideline, available at: http://www.euintangibles.net/library/localfiles/Writing\%20ICS\%202002\%20UK.pdf

Dess, G.G. and Robinson, R.B. (1984) 'Measuring organizational performance in the absence of objective measures: the case of the privately-held firm and conglomerate business unit', Strategic Management Journal, Vol. 5, No. 3, pp.265-273.

Dierickx, I. and Cool, K. (1989) 'Asset stock accumulation and sustainability of competitive advantage', Management Science, Vol. 35, No. 12, pp.1504-1511.

Dozentin, S.A.S., Flamholtz, E.G. and Bullen, M.L. (1989) 'Human resource accounting: a state-ofthe art-review', Journal of Accounting Literature, Vol. 8, pp.235-264.

Dzinkowski, R. (2000) 'The measurement and management of intellectual capital', Management Accounting, Vol. 78, No. 2, pp.32-35.

Edvinsson, L. (2002) Corporate Longitude, Stockholm: Bookhouse.

Edvinsson, L. and Malone, M. (1997) Intellectual Capital: Realising Your Company's True Value by Finding its Hidden Brainpower, New York: Harper Collins Publishers Inc.

Edvinsson, L. and Sullivan, P. (1996) 'Developing a model for managing intellectual capital', European Management Journal, Vol. 14, No. 4, pp.356-364.

Eustace, C. (2000) 'The intangible economy-impact and policy issues', report of the European High Level Expert Group on the Intangible Economy, Brussels, European Commission, Enterprise Directorate-General.

Fornell, C. and Larcker, D. (1981) 'Evaluating structural equation models with unobservable variable and measurement error', Journal of Marketing Research, Vol. 18, No. 3, pp.39-50.

Foss, N.J. (1996) 'Knowledge-based approaches to the theory of the firm: some critical comments', Organization Science, Vol. 7, No. 5, pp.470-476.

Graham, A.B. and Pizzo, V.G. (1998), 'A question of balance: case studies in strategic knowledge management', in D.A. Klein (Ed.), The Strategic Management of Intellectual Capital, Woburn, MA: Butterworth/Heinemann, pp.11-26.

Grant, R.M. (1991) 'The resource-based theory of competitive advantage: implications for strategy formulation', California Management Review, Vol. 33, No. 3, pp.114-135.

Grant, R.M. (1996) 'Toward a knowledge-based theory of the firm', Strategic Management Journal, Vol. 17, No. 2, pp.109-122.

Gröjer, J.E. and Johanson, U. (1998) 'Current development in human resource accounting: reality present-researchers absent?', Accounting, Auditing and Accountability Journal, Vol. 11, No. 4, pp.495-510.

$\mathrm{Gu}, \mathrm{F}$. and Lev, B. (2001) 'Intangible assets-measurement, drivers, usefulness', available at: http://pages.stern.nyu.edu/ blev/.

Guthrie, J., Petty, R. and Johanson, U. (2001) 'Sunrise in the knowledge economy: managing, measuring and reporting intellectual capital', Accounting, Auditing and Accountability Journal, Vol. 14, No. 4, pp.365-382.

Hansen, G. and Wernerfelt, B. (1989) 'Determinants of business performance: the relative importance of economic and organizational factors', Strategic Management Journal, Vol. 10, No. 5, pp.399-411.

Hermanson, R. (1964) 'Accounting for human assets', Occasional Paper No. 14, Michigan State University, East Lansing, MI. 
Hulland, J. (1999) 'Use of partial least squares (PLS) in strategic management research: a review of four recent studies', Strategic Management Journal, Vol. 20, No. 2, pp.195-204.

IFAC (1998) 'The measurement and management of intellectual capital: an introduction', available at: http://www.ifac.org/Store/Details.tmpl?SID=95594106759874andCart=1101399736632 4978.

Innes, J. and Mitchell, F. (1995) 'A survey of activity based costing in the U.K.'s largest companies', Management Accounting Research, Vol. 6, No. 2, pp.137-153.

Innes, J. and Mitchell, F. (1997) 'The application of activity-based costing in the United Kingdom's largest financial institutions', The Service Industries Journal, Vol. 17, No. 1, pp.190-203.

Innes, J. and Vedd, R. (1998) 'The role of management accounting in strategic human resource management', in A.D. Neely, and D.B. Waggoner (Eds), Performance Measurement - Theory and Practice, University of Cambridge, pp.515-521.

Innes, J., Mitchell, F. and Sinclair, D. (2000) 'Activity-based costing in the U.K.'s largest companies: a comparison of 1994 and 1999 survey results', Management Accounting Research, Vol. 11, No. 3, pp.349-362.

Johanson, U. (1999) 'Why the concept of human resource costing and accounting does not work', Personnel Review, Vol. 28, Nos. 1/2, pp.91-107.

Johanson, U., Martensson, M. and Skoog, M. (2001) 'Mobilizing change through the management control of intangibles', Accounting, Organizations and Society, Vol. 26, Nos. 7/8, pp.715-733.

Johnson, H.T. (1992) Relevance Regained - From Top-Down Control to Bottom-Up Empowerment, The Free Press.

Johnson, H.T. and Kaplan, R.S. (1987) Relevance Lost: The Rise and Fall of Management Accounting, Boston, MA: Harvard Business School Press.

Kaplan, R.S. and Norton, D.P. (1992) 'The balanced scorecard: measures that drive performance', Harvard Business Review, Vol. 70, No. 1, pp.71-79.

Kaplan, R.S. and Norton, D.P. (1996a) 'Using the balanced scorecard as a strategic management system', Harvard Business Review, Vol. 74, No. 1, pp.75-85.

Kaplan, R.S. and Norton, D.P. (1996b) The Balanced Scorecard: Translating Strategy into Action, Boston, MA: Harvard Business School Press.

Kasper-Fuehrer, E.C. and Ashkanasy, N.M. (2001) 'Communicating trustworthiness and building trust in interorganizational virtual organizations', Journal of Management, Vol. 27, No. 3, pp. $235-254$.

Kay, J. (1993) 'The structure of strategy', Business Strategy Review, Vol. 4, No. 2, pp.17-37.

Keeva, S. (1998) 'Keeping in front of the future', ABA Journal, Vol. 84, No. 1, pp.81-82.

Kennedy, T. and Affleck-Graves, J. (2001) 'The impact of activity-based costing on business performance', Journal of Management Accounting Research, Vol. 13, pp.19-45.

Leadbeater, C. (2000) 'New measures for the new economy', discussion paper for the Institute of Chartered Accountants in England and Wales.

Leitner, K-H. and Warden, C. (2004) 'Managing and reporting knowledge-based resources and processes in research organisations: specifics, lessons learned and perspectives', Management Accounting Research, Vol. 15, No. 1, pp.33-51.

Lev, B. (1997) 'The old rules no longer apply', Forbes, April, pp.35-36.

Litman, J. (2000) 'Genuine assets: building blocks of strategy and sustainable competitive advantage', Strategic Finance, Vol. 82, No. 5, pp.37-42.

Lord, B.R. (1996) 'Strategic management accounting: the emperor's new clothes?' Management Accounting Research, Vol. 7, No. 3, pp.347-366.

Low, J. (2002) 'The invisible advantage: getting a grasp on intangible assets', Perspectives on Business Innovation: Valuing Intangibles, Issue 7, pp.7-14.

Lynn, B.E. (2000) 'Intellectual capital - unearthing hidden value by managing intellectual assets', Ivey Business Journal, Vol. 64, No. 3, pp.48-52. 
Makadok, R. (1999) 'Interfirm differences in scale economics and the evolution of market shares', Strategic Management Journal, Vol. 20, No. 1, pp.935-952.

Marr, B. and Gray, D. (2002) 'Measuring intellectual capital - the internal and external drivers for measuring and reporting the intangibles of an organisation', paper presented at The Transparent Enterprise. The Value of Intangibles Conference, Madrid, Spain.

Mouritsen, J., Larsen, H.T. and Bukh, P.N.D. (2001) 'Intellectual capital and the "capable firm": narrating, visualising and numbering for managing knowledge', Accounting, Organizations and Society, Vol. 26, Nos. 7/8, pp.735-762.

Nonaka, I. and Takeuchi, H. (1995) The Knowledge Creating Company, UK: Oxford University Press.

Nunnally, J.C. (1978) Psychometric Theory, New York, NY: McGraw-Hill.

O'Donnell, D. and O'Regan, P. (2000) 'The structural dimensions of intellectual capital: emerging challenges for management and accounting', Southern African Business Review, Vol. 4, No. 2 , pp. 14-20.

O’Donnell, D., Bontis, N., O'Regan, P., Kennedy, T., Cleary, P. and Hannigan, A. (2004) 'CFOs in e-business: e-architects or foot-soldiers?', Knowledge and Process Management, Vol. 11, No. 2, pp.105-116

O’Donnell, D., O’Regan, P., Coates, B., Kennedy, T., Keary, B. and Berkery, G. (2003) 'Human interaction: the critical source of intangible value', Journal of Intellectual Capital, Vol. 4, No. 1, pp.82-99

Olsson, B. (1999) 'The construction of transparency through accounting on intellectual capital (IC)?', Journal of Human Resource Costing and Accounting, Vol. 4, No. 1, pp.7-10.

Oppenheim, A.N. (1966) Questionnaire Design and Attitude Measurement, London: Heinemann.

Ordonez De Pablos, P. (2002) 'Direct and indirect effects of intellectual capital on organizational competitive advantage: empirical evidence', paper presented at The Transparent Enterprise. The Value of Intangibles Conference, Madrid, Spain.

O'Regan, P., O’Donnell, D., Kennedy, T., Bontis, N. and Cleary, P. (2001) 'Perceptions of intellectual capital: Irish evidence', Journal of Human Resource Costing and Accounting, Vol. 6, No. 2, pp.29-38.

Peppard, J. and Rylander, A. (2001) 'Leveraging intellectual capital to maximize shareholder value: the case of ApiON', Proceedings of the 4th World Congress on Intellectual Capital, Hamilton, Ontario, Canada, Jan 17-19.

Perrin, S. (2000) 'Intellectual capital: measure up or lose out', Financial Director, available at: http://www.accountancyage.com/News/1102805.

Peteraf, M.A. (1993) 'The cornerstones of competitive advantage: a resource-based view', Strategic Management Journal, Vol. 14, No. 3, pp.179-191.

Petty, R. and Guthrie, J. (2000) 'Intellectual Capital literature review - measurement reporting and management', Journal of Intellectual Capital, Vol. 1, No. 2, pp.155-176.

Pierce, B. and O'Dea, T. (2003) 'Management accounting information and the needs of managers: perceptions of managers and accountants compared', The British Accounting Review, Vol. 35, No. 3, pp.257-290.

Pilch, T. (2000) Dynamic Reporting for a Dynamic Economy, London: The Smith Institute, available at: http://www.academyofenterprise.org/downloads/smith_for_web.doc.

Raghurum, S., Garud, R., Wiesenfeld, B. and Gupta, V. (2001) 'Factors contributing to virtual work adjustment', Journal of Management, Vol. 27, No. 3, pp.383-405.

Ratnatunga, J. (2002) 'The valuation of capabilities: a new direction for management accounting research', Journal of Applied Management Accounting Research, Vol. 1, No. 1, pp 1-15.

Ratnatunga, J., Gray, N. and Balachandran, K.R. (2004) 'CEVITATM: the valuation and reporting of strategic capabilities’, Management Accounting Research, Vol. 15, No. 1, pp.77-105. 
Roberts, H. (2003), 'Management accounting and the knowledge production process', in A. Bhimani (Ed.), Management Accounting in the Digital Economy, New York: Oxford University Press, pp.260-283.

Robins, J. and Wiersema, M. F. (1995) 'A resource-based approach to the multibusiness firm: empirical analysis of portfolio relationships and corporate financial performance', Strategic Management Journal, Vol. 16, No. 4, pp.277-299.

Rogers, E.W. (2001) 'A theoretical look at business performance in high-tech organizations. What does existing theory tell us?', Journal of High Technology Management Research, Vol. 12, No. 1, pp.39-61.

Roos, J., Roos, G., Edvinsson L. and Dragonetti, N.C. (1997) Intellectual Capital: Navigating in the New Business Landscape, London: Macmillan.

Roslender, R. (1997) 'Accounting for the worth of employees: is the discipline finally ready to respond to the challenge', Journal of Human Resource Costing and Accounting, Vol. 2, No. 1, pp.9-26.

Roslender, R. (2000) 'Accounting for intellectual capital - a contemporary management accounting perspective', Management Accounting, Vol. 78, No. 3, pp.34-37.

Roslender, R. and Dyson, J.R. (1992) 'Accounting for the worth of employees: a new look at an old problem', The British Accounting Review, Vol. 24, No. 4, pp.311-329.

Roslender, R. and Fincham, R. (2001) 'Thinking critically about intellectual capital accounting', Accounting, Auditing and Accountability Journal, Vol. 14, No. 4, pp.383-399.

Roslender, R. and Fincham, R. (2004) 'Intellectual capital accounting in the UK: a field study perspective', Accounting, Auditing and Accountability Journal, Vol. 17, No. 2, pp.178-209.

Saint-Onge, H. (1996) 'Tacit knowledge: the key to the strategic alignment of intellectual capital', Strategy and Leadership, Vol. 24, No. 2, pp.10-14.

Saxe, R. and Weitz, B. (1982) 'The SOCO Scale: a measure of the customer orientation of salespeople', Journal of Marketing Research, Vol. 19, No. 3, pp.343-351.

Serenko, A. and Bontis, N. (2004) 'Meta-review of knowledge management and intellectual capital literature: citation impact and research productivity rankings', Knowledge and Process Management, Vol. 11, pp.185-198.

Skoog, M. (2002) 'Visualizing value creation through the management control of intangibles', paper presented at The Transparent Enterprise. The Value of Intangibles Conference, Madrid, Spain.

Spender, J-C. (1996) 'Making knowledge the basis of a dynamic theory of the firm', Strategic Management Journal Special Issue, Vol. 17, pp.45-62.

Spender, J-C. and Grant, R.M. (Eds) (1996) 'Knowledge and the firm: overview', Strategic Management Journal Special Issue, Vol. 17, pp.5-9.

Stewart, T.A. (1997) Intellectual Capital: The Wealth of New Organisations, New York, NY: Doubleday.

Stewart, T.A. (2002) The Wealth of Knowledge: Intellectual Capital and the Twenty-first Century Organization, New York: Doubleday.

Sveiby, K-E. (1997) The New Organisational Wealth: Managing and Measuring Knowledge Based Assets, San Francisco, CA: Berret-Koehler.

Turner, G. (1996) 'Human resource accounting-whim or wisdom?', Journal of Human Resource Costing and Accounting, Vol. 1, No. 1, pp.63-73.

Von Krogh, G. and Roos, J. (1996) Managing Knowledge: Perspectives on Co-operation and Competition, London: Sage.

Von Krogh, G., Ichijo, K. and Nonaka, I. (2000) Enabling Knowledge Creation: How to Unlock the Mystery of Tacit Knowledge and Release the Power Of Innovation, New York: Oxford University Press.

Williams, J.R. (1992) 'How sustainable is your competitive advantage', California Management Review, Vol. 34, No. 3, pp.29-51. 